\title{
Lutein and $\beta$-Cryptoxanthin Inhibit Inflammatory Mediators in Human Chondrosarcoma Cells Induced with IL-1ß
}

\author{
Michael M. Di Filippo, Bridget D. Mathison, Jean Soon Park and Boon P. Chew*
}

School of Food Science, Washington State University, Pullman, WA 99164-6376, USA

\begin{abstract}
Objective: Studies have shown that lutein $(\mathrm{Lu})$ and $\beta$-cryptoxanthin $(\beta \mathrm{Cr})$ may down-regulate factors involved in inflammation associated with osteoarthritis and rheumatoid arthritis. We studied the possible protective effects of Lu and $\beta \mathrm{Cr}$ in vitro against human chondrocyte dysfunction using a human chondrosarcoma cell line.

Methods: SW-1353 human chondrosarcoma cells were cultured for $24 \mathrm{hr}$ in supplemented medium containing $0,0.01,0.1$ or $1.0 \mu \mathrm{mol} / \mathrm{L}$ of $\mathrm{Lu}$ or $\beta \mathrm{Cr}$ and subsequently stressed for $24 \mathrm{hr}$ in the presence of $10 \mu \mathrm{g} / \mathrm{L} \mathrm{IL}-1 \beta$. The resulting conditioned medium was analyzed for matrix-metalloproteinase-13 (MMP-13), cytokines (IL-1 $\alpha$, IL-2, IL-4, IL-10, IFN- $\gamma$, IL6 , IL-8, and TNF- $\alpha$ ), and PGE2. Nuclear extract from the harvested cells was analyzed for NFKB.

Results: $\mathrm{Lu}(1.0 \mu \mathrm{mol} / \mathrm{L} ; \mathrm{P}<0.05)$ but not $\beta \mathrm{Cr}$ decreased MMP-13. Both $\mathrm{Lu}(1.0 \mu \mathrm{mol} / \mathrm{L} ; \mathrm{P}<0.05)$ and $\beta \mathrm{Cr}(0.1$ and 0.01 $\mu \mathrm{mol} / \mathrm{L} ; \mathrm{P}<0.01)$ inhibited $\mathrm{PGE}_{2}$ production. All concentrations of $\beta \mathrm{Cr}$ suppressed $(\mathrm{P}<0.05)$ IL- $1 \alpha$, IL-2 and IFN- $\gamma$ production while $\mathrm{Lu}$ increased concentrations of these cytokines. Lu increased $(\mathrm{P}<0.05)$ while $\beta \mathrm{Cr}$ decreased IL-4 and IL-10 concentrations. $\mathrm{NF} \kappa \mathrm{B}$ p50 production was suppressed $(\mathrm{P}<0.01)$ by both $\mathrm{Lu}$ and $\beta \mathrm{Cr}$, with Lu being more inhibitory.

Conclusion: Therefore, $\mathrm{Lu}$ and $\beta \mathrm{Cr}$ protected against IL-1 $\beta$-induced chondrocyte dysfunction by down-regulating NF $\mathrm{BB}$ activation and inhibiting inflammatory response, albeit through somewhat different pathways.
\end{abstract}

Keywords: Lutein, $\beta$-Cryptoxanthin, Arthritis, Human chondrosarcoma, Inflammatory mediators.

\section{INTRODUCTION}

Osteoarthritis $(\mathrm{OA})$ is a musculoskeletal disorder that involves the degeneration of articular cartilage, intraarticular inflammation with synovitis, and alterations in periarticular and subchondral bone [1]. Rheumatoid arthritis (RA) is a chronic autoimmune disease characterized by the localization of inflammatory cells in the synovial lining, leading to joint erosion and progressive bone and articular cartilage destruction [2]. In 2005, OA and RA affected 27 and 1.3 million adults, respectively $[3,4]$. OA originates in the cartilage and may spread to synovial tissue encompassing the joint, while RA begins in the synovial tissue adjacent to the joint before spreading to cartilage [5]. Despite differing pathogenesis, the activation of matrix-degrading proteinases and the production of inflammatory cytokines and mediators, specifically those produced by chondrocytes in articular cartilage, are very similar.

Research has shown that IL-1 $\beta$ is the key force in promoting an imbalance between cartilage degradation and repair $[6,7]$. Several studies have implicated reactive oxygen species (ROS) in IL-1-mediated cellular responses [8,9]. Induction of apoptosis in chondrocytes by IL-1 $\beta$ leads to increased cellular generation of reactive oxygen species (ROS), and the ensuing upregulation of $\mathrm{NF \kappa B}$ and production of matrix-degrading proteinases, inflammatory cytokines, and mediators.

*Address correspondence to this author at the School of Food Science, FSHN 110, Washington State University, Pullman, WA 99164-6376, USA; Tel: 509-335-1427; Fax: 509-335-4815; E-mail: boonchew@wsu.edu
Lutein $(\mathrm{Lu})$ and $\beta$-cryptoxanthin $(\beta \mathrm{Cr})$, naturally occurring, food-derived carotenoids [10], must be derived from the diet. Lu has been shown to prevent systemic inflammation in response to lipopolysaccaride (LPS), and to modulate immune and inflammatory responses by regulating redox potentials $[11,12]$. In $\mathrm{OA}$ and $\mathrm{RA}$, upregulation of $\mathrm{NF \kappa B}$ results in increased production of pro-inflammatory cytokines and mediators, along with collagen degrading proteinases. $\mathrm{Lu}$ is effective in reducing intracellular accumulation of the highly potent ROS $\mathrm{H}_{2} \mathrm{O}_{2}$ in murine macrophages, resulting in downregulation of $\mathrm{NF \kappa B}$ [2]. $\beta \mathrm{Cr}$ has been found to be associated with a reduced risk of developing inflammatory polyarthritis [13]. Even though the protective effects of $\mathrm{Lu}$ and $\beta \mathrm{Cr}$ on the cellular mechanism in arthritic chondrocytes is not known, it is likely that $\beta \mathrm{Cr}$ is involved in downregulating NFKB activation through its potent antioxidant activity.

The SW-1353 cell line has been shown to be a suitable model for examining pathological factors in OA and RA. It has strong similarities to primary human chondrocytes with respect to catabolic effects after treatment with IL-1 $\beta$, including activation of the transcriptional regulator NFkB and subsequent production of MMP-1, MMP-3, and MMP-13 [14]. IL-1 $\beta$ can activate the three MAPK pathways $p 38$, ERK, and JNK in SW-1353 cells, and leads to downstream activation of the transcriptional factor AP-1 $[15,16]$. It was recently shown that $\mathrm{p} 38$ regulates IL- $1 \beta$ stimulation of both MMP-1 and MMP-13 [17], which is consistent with previous reports of a dose-dependent decrease in the production of MMP-13 and MMP-1 when SW-1353 cells were treated with p38 kinase inhibitor [18]. This indicates that the SW-1353 
cell line is an appropriate model for investigating IL-1 $\beta$ induced joint degeneration.

The objective of this study is to assess the protective effect of the carotenoids, $\mathrm{Lu}$ and $\beta \mathrm{Cr}$, on $\mathrm{NF} \kappa \mathrm{B}$ activation, inflammatory response, and proteinase production in SW1353 human chondrosarcoma cells induced with IL-1 $\beta$. We hypothesize that $\mathrm{Lu}$ and $\beta \mathrm{Cr}$ will reduce inflammatory response and proteinase production by downregulating NFKB.

\section{MATERIALS AND METHODOLOGY}

\section{Materials}

Human SW-1353 chondrosarcoma cells were purchased from the American Type Culture Collection (Manassas, VA). DMEM, penicillin G, streptomycin sulfate, amphotericin B, trypsin-EDTA, tetrahydrofuran, and the carotenoids lutein and $\beta$-Cryptoxanthin were purchased from Sigma Aldrich (St. Louis, MO), newborn calf serum from HyClone (Logan, UT), and the Micro BCA Protein Assay Kit was from Pierce (Rockford, IL). The ELISA for MMP13 was purchased from AnaSpec (San Jose, CA), $\mathrm{PGE}_{2}$ from R\&D Systems (Minneapolis, MN), cytokines from Quansys (Logan, UT), and NFאB (human p50) from Cayman Chemical (Ann Arbor, MI).

\section{Cell Culture}

Human SW-1353 chondrosarcoma cells (ATCC; Manassas, VA) were cultured in DMEM supplemented with 100 units $/ \mathrm{mL}$ penicillin $\mathrm{G}, 100 \mu \mathrm{g} / \mathrm{mL}$ streptomycin sulfate, 0.25 $\mu \mathrm{g} / \mathrm{mL}$ amphotericin $\mathrm{B}$, and $10 \%$ newborn calf serum, at $37^{\circ} \mathrm{C}$ in a humidified $5 \% \mathrm{CO}_{2}$ atmosphere. All experiments were conducted using cells within 2 passage numbers. Cells were plated at $2 \times 10^{5}$ cells/well in 6 well plates and incubated for $48 \mathrm{~h}$. Cell medium was removed and replaced with supplemented medium containing $0,0.01,0.1$, or $1.0 \mu \mathrm{mol} / \mathrm{L}$ Lu (Expt. 1) or $\beta \mathrm{Cr}$ (Expt. 2). The carotenoids were prepared immediately before use by solubilizing in tetrahydrofuran (THF), gradually adding to NCS with continual stirring, followed by addition of DMEM to give a final concentration of $5 \%$ serum. ( $0.1 \%$ THF final concentration). Control cultures contained $0.1 \%$ THF but no carotenoid; previous research has shown tetrahydrofuran is a suitable solvent for carotenoids in cell culture [19]. The cells were incubated with carotenoid for $24 \mathrm{~h}$, medium removed, $10 \mathrm{ng}$ IL- $1 \beta / \mathrm{mL}$ DMEM added, and incubated for an additional $18 \mathrm{~h}$. Cells that received $0 \mu \mathrm{mol} / \mathrm{L}$ carotenoid and no IL- $1 \beta$ served as negative controls, and cells that received $0 \mu \mathrm{mol} / \mathrm{L}$ carotenoid and $10 \mathrm{ng}$ IL- $1 \beta / \mathrm{mL}$ served as positive controls. Conditioned medium (CM) following incubation with IL-1 $\beta$ was collected and stored at $-80^{\circ} \mathrm{C}$ until assay. The adherent cells were dissociated from the wells with trypsin-EDTA and counted using a Coulter counter (Beckman Coulter, Brea, CA). Cell pellets were snap-frozen and stored at $-80^{\circ} \mathrm{C}$.

\section{Assays}

Total latent and active matrix metalloproteinase-13 (MMP-13) in the CM were analyzed using a commercially available ELISA kit (SensoLyte MMP-13 ELISA Kit, AnaSpec, San Jose, CA, USA). Since MMP-13 is a key enzyme facilitating breakdown of cartilage in arthritis, it is useful in examining potential inhibitors of this process. The lower limit of detection for MMP-13 was $\leq 6 \mathrm{pg} / \mathrm{ml}$.
$\mathrm{PGE}_{2}$ was analyzed by ELISA (Parameter $\mathrm{PGE}_{2}, \mathrm{R} \& \mathrm{D}$ Systems, Minneapolis, MN, USA) and the lower limit of detection for $\mathrm{PGE}_{2}$ was $8.5 \mathrm{pg} / \mathrm{ml}$.

Pro-inflammatory cytokines IL- $1 \alpha$, IL- 2, IFN- $\gamma$, IL-6, IL8 , TNF- $\alpha$ and anti-inflammatory cytokines IL-4, IL-10 were analyzed in CM by chemiluminescent array format ELISA (Quansys Q-Plex Cytokine Array, Logan, UT). This assay simultaneously measures multiple cytokines. Digital images (Canon EOS 40D, Canon, Irvine, CA, USA) were acquired using imaging capture software (Digital Imaging Professional 3.3, Canon, Irvine, CA, USA). Data obtained was analyzed using Quansys Q-View 2.5.2 software (Quansys QPlex Cytokine Array, Logan, UT). The lower limit of detection was $4.10,1.10, \leq 1.0, \leq 1.0,1.36,2.11,1.36$, and $\leq 1.0$ $\mathrm{pg} / \mathrm{mL}$ for IL- $1 \alpha$, IL-2, IFN- $\gamma$, IL-6, IL-8, TNF- $\alpha$, IL-4, and IL-10, respectively.

Nuclear extract NFкB p50 was analyzed in the cell pellets using a commercially available ELISA kit (NFkB (human 50) Transcription Factor Assay, Cayman Chemical, Ann Arbor, MI, USA). This assay requires purification of cellular nuclear extracts. Due to inadequate cell numbers, cell pellets from 3 samples in each treatment were pooled for analysis of NFKB. All buffer reagents were purchased from Sigma Aldrich (St. Louis, MO, USA). Percent change was calculated by dividing the optical density of each treatment sample by the corresponding positive control (IL-1 $\beta$ only).

Total protein in the nuclear extract were analyzed using a colorimetric assay (Micro BCA Protein Assay Kit, Pierce, Rockford, IL, USA). The lower limit of detection for protein was $0.5 \mu \mathrm{g} / \mathrm{ml}$.

\section{Statistical Analysis}

Data was analyzed by one-way analysis of variance (ANOVA) using the General Linear Models procedure of SAS, and treatment means were compared with protected LSD. A probability value of $P<0.05$ was considered statistically significant.

\section{RESULTS}

\section{Matrix Metalloproteinase}

MMP-13 concentrations in the cell supernatants was expressed as ng total MMP- $13 / 10^{6}$ to standardize amounts between cultures. Basal concentrations of total MMP-13 in SW-1353 cell cultures without IL-1 $\beta$ stimulation (negative control) averaged $0.027 \pm 0.003$ and $0.031 \pm 0.008 \mathrm{ng} / 10^{6}$ cells for the $\mathrm{Lu}$ and $\beta \mathrm{Cr}$ experiments, respectively (Fig. 1). In the presence of IL-1 $\beta$ (positive control), MMP-13 production increased $(P<0.01)$, with concentrations reaching $4.97 \pm$ $0.50 \mathrm{ng} / 10^{6}$ cells for $\mathrm{Lu}$ and $4.21 \pm 0.30 \mathrm{ng} / 10^{6}$ cells for $\beta \mathrm{Cr}$. Pre-incubating cultures with Lu decreased MMP-13 concentration in a dose-dependent manner following IL- $1 \beta$-induced stress. Concentrations of MMP-13 in cultures pre-incubated with $1.0 \mu \mathrm{mol} / \mathrm{L} \mathrm{Lu}$ were approximately $35 \%(P<0.02)$ those without $\mathrm{Lu}$. Conversely, $\beta \mathrm{Cr}$ did not influence MMP-13 production, although MMP-13 concentrations in the presence of $0.01 \mu \mathrm{mol} / \mathrm{L} \beta \mathrm{Cr}$ tended to be lower than cultures without $\beta \mathrm{Cr}$.

\section{$\mathrm{PGE}_{2}$ Production}

Addition of IL-1 $\beta$ slightly stimulated $\mathrm{PGE}_{2}$ production (Fig. 2), when compared with negative control. Production 


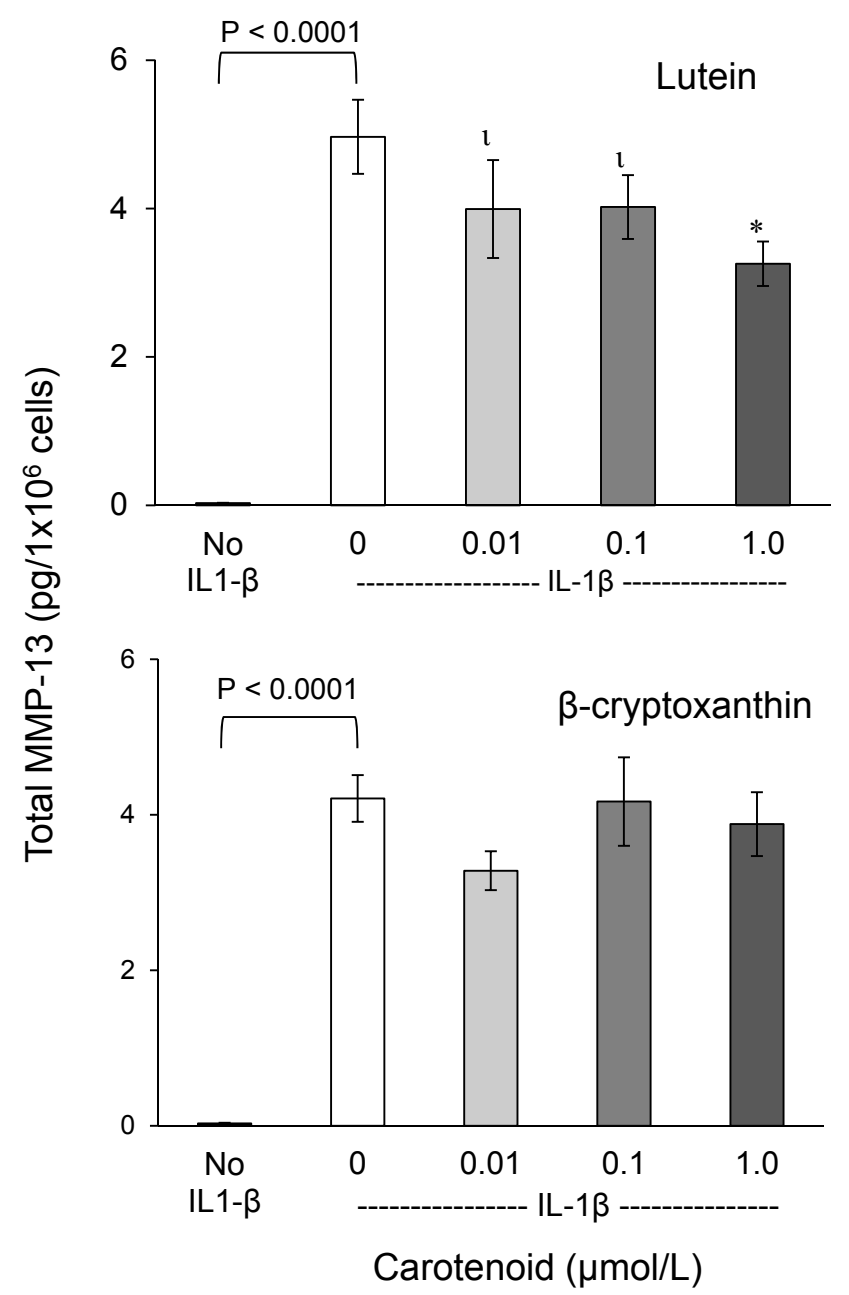

Fig. (1). Production of MMP-13 (mean \pm SEM) by SW-1353 cells incubated in the presence of $0,0.01,0.1$, or $1.0 \mu \mathrm{mol} / \mathrm{L}$ lutein or $\beta$ cryptoxanthin and stimulated with $10 \mathrm{ng} / \mathrm{mL}$ IL-1 $\beta$. Negative control wells (no IL-1 $\beta$ ) were incubated with neither carotenoid nor IL1及. Data were analyzed by ANOVA. ${ }^{*} \tau$ Statistically different from $0 \mu \mathrm{mol} / \mathrm{L}$ carotenoid control $\left({ }^{*} P<0.05,{ }^{\tau} P<0.06\right)$.

of $\mathrm{PGE}_{2}$ decreased in a dose-dependent manner when cells were cultured in the presence of $\mathrm{Lu}$, with a significant suppression of $\mathrm{PGE}_{2}$ following incubation with $1.0 \mu \mathrm{mol} / \mathrm{L} \mathrm{Lu}$ $(P<0.05)$. There was also a significant $(\mathrm{P}<0.05)$ decrease in $\mathrm{PGE}_{2}$ production with 0.01 and $0.1 \mu \mathrm{mol} / \mathrm{L} \beta \mathrm{Cr}$ but not with the highest concentration.

\section{Cytokine Production}

The effects of $\mathrm{Lu}$ on the production of the proinflammatory cytokines IL- $1 \alpha$, IL-1 $\beta$, IL- 6 , IL- 8 and TNF- $\alpha$ are presented in Table 1. Addition of IL-1 $\beta$ into cultures without the carotenoids increased $(P<0.01)$ IL-1 $\alpha$ production one to two fold. While $\mathrm{Lu}$ did not influence IL-1 $\alpha$ production, the highest concentration of $\beta C r$ inhibited $(\mathrm{P}<0.05)$ IL$1 \alpha$ concentrations (Table 2 ).

The presence of IL-1 $\beta$ alone increased $(P<0.05)$ IL-2 concentrations $85(\mathrm{Lu})$ to $250 \%(\beta \mathrm{Cr})$. At $0.1 \mu \mathrm{mol} / \mathrm{L}, \mathrm{Lu}$ increased $(P<0.01)$ IL-2 concentrations by $85 \%$. Conversely, addition of $\beta \mathrm{Cr}$, especially at 0.1 and $1.0 \mu \mathrm{mol} / \mathrm{L}$ produced a dose-dependent decrease in IL-2 concentrations.

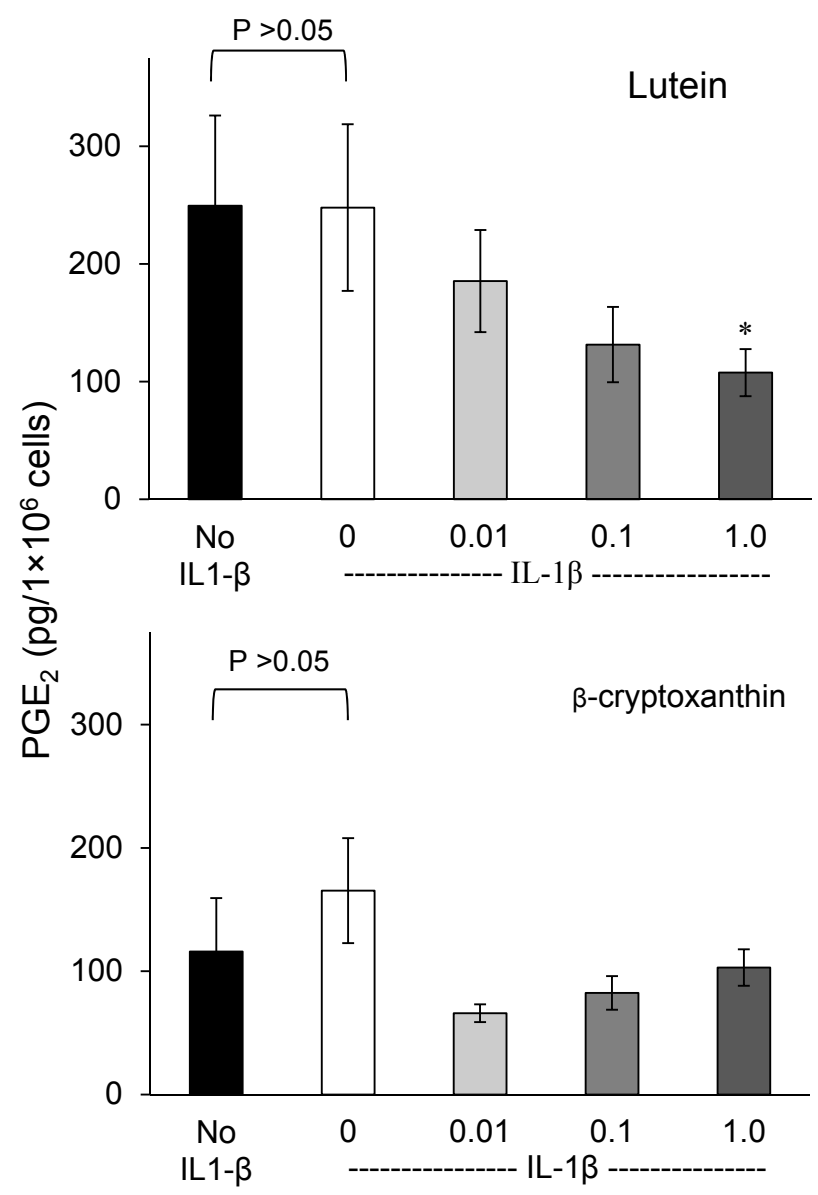

\section{Carotenoid $(\mu \mathrm{mol} / \mathrm{L})$}

Fig. (2). Production of $\mathrm{PGE}_{2}$ (mean \pm SEM) by SW-1353 cells incubated in the presence of $0,0.01,0.1$, or $1.0 \mu \mathrm{mol} / \mathrm{L}$ lutein or $\beta$ cryptoxanthin and stimulated with $10 \mathrm{ng} / \mathrm{mL}$ IL-1 $\beta$. Negative control wells (no IL-1 $\beta$ ) were incubated with neither carotenoid nor IL$1 \beta$. Data were analyzed by ANOVA. ${ }^{*}$ Statistically different from 0 $\mu \mathrm{mol} / \mathrm{L}$ carotenoid control $(P<0.05)$.

IL-1 $\beta$ stimulated $(P<0.05)$ IFN- $\gamma$ production by SW-1353 cells in both studies. At the highest concentration, $\mathrm{Lu}$ increased $(P<0.06) \mathrm{IFN}-\gamma$ concentration. In contrast, 0.1 and $1.0 \mu \mathrm{mol} / \mathrm{L} \beta \mathrm{Cr}$ inhibited IFN- $\gamma$ production.

In the presence of IL- $1 \beta$ alone, production of IL- 6 , IL-8, and TNF- $\alpha$ increased significantly $(P<0.01)$. Neither Lu nor $\beta \mathrm{Cr}$ significantly influenced IL- 6 , IL- 8 , or TNF- $\alpha$ production.

The effects of $\mathrm{Lu}$ and $\beta \mathrm{Cr}$ on the production of the antiinflammatory cytokines IL-4 and IL-10 are presented in Tables 1 and 2. The presence of IL- $1 \beta$ alone stimulated $(\mathrm{P}<0.01)$ IL-4 production $166 \%$ and $283 \%$ in $\mathrm{Lu}$ and $\beta \mathrm{Cr}$, respectively. While $\mathrm{Lu}$ increased $(\mathrm{P}<0.01)$ IL-4 production in a dose-dependent manner, $\beta \mathrm{Cr}$ had no significant effect.

IL-1 $\beta$ alone stimulated $(P<0.01)$ IL-10 production, and $\beta C r$ was inhibitory, with a significant $(\mathrm{P}<0.05)$ inhibition observed with $1.0 \mu \mathrm{mol} / \mathrm{L}$. In contrast, Lu had no significant effect on IL-10 production. 
Table 1. Cytokine Response $(\mathrm{pg} / \mathrm{mL})$ by SW-1353 Cells Incubated in the Presence of 0, 0.01, 0.1, or 1.0 $\mu \mathrm{mol} / \mathrm{L} \mathrm{Lutein}$ and Stimulated with $10 \mathrm{ng} / \mathrm{mL}$ IL-1ß

\begin{tabular}{|c|c|c|c|c|c|}
\hline & & \multicolumn{4}{|c|}{ Lutein $(\mu \mathrm{mol} / \mathrm{L})$} \\
\hline & & $\mathbf{0}$ & 0.01 & 0.1 & 1.0 \\
\hline Cytokine & No IL-1及 & \multicolumn{4}{|c|}{ - IL-1 - } \\
\hline IL-1 $\alpha$ & $4.7 \pm 0.8$ & $9.2 \pm 1.0$ & $9.1 \pm 0.7$ & $9.9 \pm 0.7$ & $13.1 \pm 2.6$ \\
\hline IL-2 & $10.2 \pm 0.9$ & $18.9 \pm 1.4$ & $25.1 \pm 3.0$ & $35.0 \pm 4.2 *$ & $21.9 \pm 2.0$ \\
\hline IL-4 & $3.8 \pm 0.3$ & $10.1 \pm 1.8$ & $17.7 \pm 1.1$ & $22.3 \pm 2.1 *$ & $23.0 \pm 6.7^{*}$ \\
\hline IL-10 & $4.5 \pm 0.6$ & $13.9 \pm 2.7$ & $19.2 \pm 2.9$ & $16.5 \pm 2.5$ & $11.9 \pm 1.4$ \\
\hline IFN- $\gamma$ & $3.2 \pm 0.2$ & $4.9 \pm 0.5$ & $6.6 \pm 0.7$ & $7.0 \pm 0.5$ & $8.7 \pm 2.5$ \\
\hline TNF- $\alpha$ & $8.1 \pm 0.7$ & $37.5 \pm 3.6$ & $41.7 \pm 5.0$ & $42.3 \pm 2.5$ & $42.2 \pm 4.5$ \\
\hline
\end{tabular}

Values $(\mathrm{n}=6)$ are mean \pm SEM.

${ }^{*}$ Statistically different from control $(P<0.05)$.

Table 2. Cytokine Response (pg/mL) by SW-1353 Cells Incubated in the Presence of 0, 0.01, 0.1, or 1.0 $\mu \mathrm{mol} / \mathrm{L} \beta$-Cryptoxanthin and Stimulated with $10 \mathrm{ng} / \mathrm{mL}$ IL-1ß

\begin{tabular}{|c|c|c|c|c|c|}
\hline & & \multicolumn{4}{|c|}{$\beta$-Cryptoxanthin $(\mu \mathrm{mol} / \mathrm{L})$} \\
\hline & & $\mathbf{0}$ & 0.01 & 0.1 & 1.0 \\
\hline Cytokine & No IL-1及 & \multicolumn{4}{|c|}{ 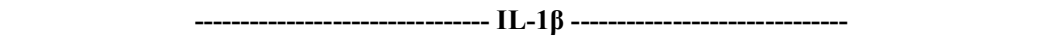 } \\
\hline IL-1 $\alpha$ & $3.0 \pm 0.5$ & $8.9 \pm 1.3$ & $6.4 \pm 0.7$ & $7.9 \pm 1.1$ & $6.1 \pm 0.6^{*}$ \\
\hline IL-2 & $7.6 \pm 0.4$ & $26.7 \pm 7.6$ & $17.6 \pm 1.5$ & $14.8 \pm 1.0^{*}$ & $14.7 \pm 1.3^{*}$ \\
\hline IL-4 & $3.0 \pm 0.1$ & $11.5 \pm 2.8$ & $10.8 \pm 2.5$ & $10.1 \pm 1.8$ & $7.0 \pm 0.9$ \\
\hline IL-6 & $7.0 \pm 5.3$ & $294.1 \pm 32.8$ & $377.6 \pm 75.9$ & $293.7 \pm 39.7$ & $347.4 \pm 63.4$ \\
\hline IL-8 & $28.5 \pm 12.2$ & $226.2 \pm 11.6$ & $228.1 \pm 12.8$ & $209.9 \pm 9.3$ & $215.7 \pm 7.9$ \\
\hline IL-10 & $3.0 \pm 0.4$ & $10.8 \pm 2.2$ & $8.7 \pm 1.3$ & $7.6 \pm 0.7$ & $6.1 \pm 0.9^{*}$ \\
\hline IFN- $\gamma$ & $2.2 \pm 0.0$ & $11.5 \pm 1.3$ & $7.2 \pm 1.0$ & $4.4 \pm 0.5$ & $4.5 \pm 0.5$ \\
\hline TNF- $\alpha$ & $5.7 \pm 0.6$ & $32.5 \pm 4.5$ & $35.8 \pm 2.6$ & $34.2 \pm 5.2$ & $26.1 \pm 1.2$ \\
\hline
\end{tabular}

Values $(\mathrm{n}=6)$ are mean \pm SEM.

${ }^{*}$ Statistically different from control $(P<0.05)$.

\section{NFKB (P50)}

The addition of IL- $1 \beta$ to the chondrocyte culture stimulated $\mathrm{NF \kappa B}$ expression $79 \%(\mathrm{Lu})$ to $270 \%(\beta \mathrm{Cr})$, when compared to negative control. However, 0.01 and $0.1 \mu \mathrm{mol} / \mathrm{L} \mathrm{Lu}$ significantly down-regulated $(\mathrm{P}<0.01)$ p50 expression by approximately 32 to $39 \%$, respectively, compared to control cultures (Fig. 3). Only the highest concentration $(1 \mu \mathrm{mol} / \mathrm{L})$ of $\beta \mathrm{Cr}$ reduced $(\mathrm{P}<0.01)$ p50 expression to approximately the same magnitude.

\section{DISCUSSION}

We studied the possible protective effects of $\mathrm{Lu}$ and $\beta \mathrm{Cr}$ against IL-1 $\beta$-induced inflammation, proteinase production and NFKB (p50) expression in vitro using human chondrosarcoma cells. Overall, preincubation of cells with $\mathrm{Lu}$ and $\beta \mathrm{Cr}$ resulted in a protection against IL-1 $\beta$-induced inflammatory response.

$\mathrm{NF \kappa B}$, present in chondrocyte cytosol in the inactive form, IкB, can be activated by inflammatory stimuli such as
IL-1 $\beta$, TNF- $\alpha$, and lipopolysaccaride (LPS), and this upregulation of $\mathrm{NF \kappa B}$ leads to increased production of proinflammatory cytokines, pro-inflammatory mediators $\left(\mathrm{PGE}_{2}\right.$ and $\mathrm{NO}$ ), and type II collagen degrading proteinases (such as MMP-13) [2,20]. Similarly, Li and Engelhardt showed that ROS, such as $\mathrm{NO}$ and $\mathrm{H}_{2} \mathrm{O}_{2}$, can activate the $\mathrm{NF \kappa B}$ pathway. Intracellular signals activate the IKB kinase (IKK) complex inducing phosphorylation and degradation of IкB [21], nuclear appearance of p50 and p65, and the subsequent transcriptional induction of inflammation-associated genes that encode the pro-inflammatory cytokines, iNOS, COX-2, and MMP-13 [2].

Preincubation of IL-1 $\beta$-stimulated SW-1353 cells with the carotenoids $\mathrm{Lu}$ and $\beta \mathrm{Cr}$ significantly down-regulated nuclear p50 expression, with Lu being 100 fold more suppressive than $\beta C$. Similarly, Kim et al., reported that 10

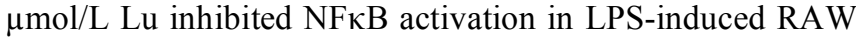
264.7 cells [2]. Yamaguchi and Uchiyama showed that 0.1 $\mu \mathrm{mol} / \mathrm{L} \beta \mathrm{Cr}$ was not able to downregulate NFKB activation in osteoclastic cells [22]. This indicates that $\beta \mathrm{Cr}$ is required 
in higher concentrations $(1.0 \mu \mathrm{mol} / \mathrm{L}$ in this study) to prevent p50 translocation into the nucleus.

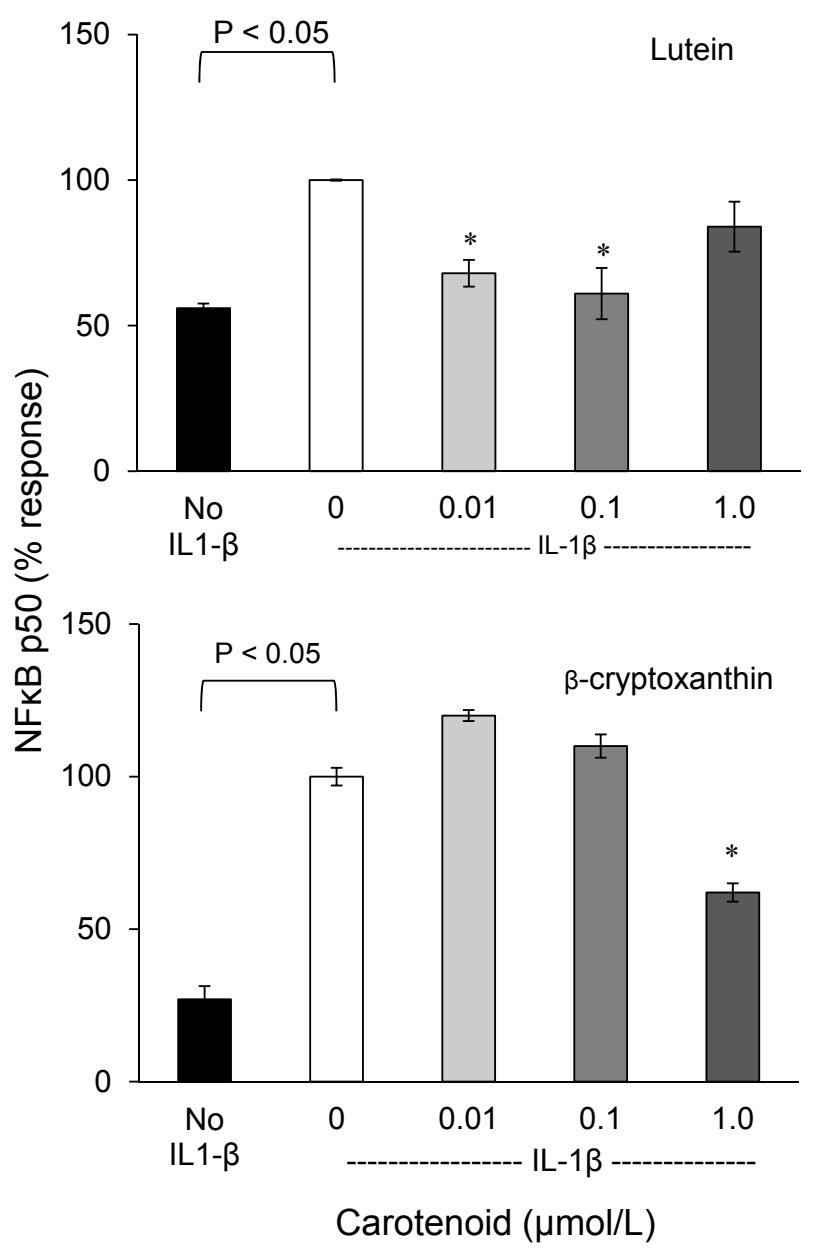

Fig. (3). Production of NFאB p50 (mean \pm SEM) in SW-1353 cells incubated in the presence of $0.01,0.1$, or $1 \mu \mathrm{mol} / \mathrm{L}$ lutein or $\beta$ cryptoxanthin and stimulated with $10 \mathrm{ng} / \mathrm{mL}$ IL-1 $\beta$. Negative control wells (no IL-1 $\beta$ ) were incubated with neither carotenoid nor IL$1 \beta$. Data were analyzed by ANOVA. ${ }^{*}$ Statistically different from 0 $\mu \mathrm{mol} / \mathrm{L}$ carotenoid control $(P<0.05)$.

The ability of antioxidants to down-regulate NF- $\kappa \mathrm{B}$ activation is likely due to their potent scavenging of ROS [23], as was seen in human chondrocytes pretreated with carotenoids, which resulted in clearance of ROS and inhibition of ligands required for downstream $\mathrm{NF \kappa B}$ activation. In our studies, ROS generated in response to IL-1 $\beta$ were indeed reduced in cultures that were pre-incubated with both $\mathrm{Lu}$ and $\beta \mathrm{Cr}$ (unpublished data).

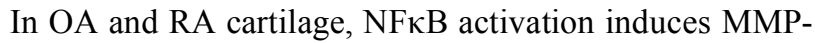
13 production, resulting in the loss of type II collagen, tensile properties, and structural integrity of the affected joint. Numerous studies have demonstrated the ability of IL- $1 \beta$ to induce MMP-13 production in chondrocytes [24,25]. Gebauer et al., confirmed that SW-1353 cells and primary human adult articular chondrocytes were also similar in producing increased amounts of MMP-13 in response to IL-1 $\beta$ stimulation [14]. The present study shows that physiological concentrations $(0.01-1.0 \mu \mathrm{mol} / \mathrm{L})$ of $\mathrm{Lu}$ can decrease IL-1 $\beta$ induced production of MMP-13 in SW-1353 cells and thereby protect against type II collagen degradation. In contrast, $\beta \mathrm{Cr}$ did not exert a similar effect.

$\mathrm{PGE}_{2}$ is a major pro-inflammatory mediator in arthritic diseases, and has been reported to not only potentiate inflammation but also inhibit proteoglycan synthesis [26]. Nitric oxide (NO) contributes to the development of OA and RA by mediating catabolic responses mediated by proinflammatory cytokines such as IL-1 $\beta$. The IL-1 $\beta$-induced upregulation $\mathrm{NF} \kappa \mathrm{B}$ in chondrocytes results in production of $\mathrm{PGE}_{2}$ and NO through COX-2 and iNOS activation, respectively [27]. In this study, both $\mathrm{Lu}(1.0 \mu \mathrm{mol} / \mathrm{L})$ and $\beta \mathrm{Cr}(0.01$ and $0.1 \mu \mathrm{mol} / \mathrm{L}$ ) decreased $\mathrm{PGE}_{2}$ concentrations, suggesting that $\mathrm{Lu}$, and especially $\beta \mathrm{Cr}$, can alleviate $\mathrm{PGE}_{2}$-modulated inflammation and joint degeneration common in $\mathrm{OA}$ and RA. Retinoic acid has also been shown to inhibit $\mathrm{PGE}_{2}$ production in IL-1-induced human primary chondrocytes, and suppress nitric oxide, and iNOS and COX-2 expression, suggesting that the action is mediated through the suppression of JNK-AP-1 signaling pathway [27]. While $\beta \mathrm{Cr}$ has provitamin A activity, lutein does not; therefore the actions of these carotenoids are unlikely due to prior conversion to vitamin A.

IL-1 $\beta$ can also induce chondrocytes to produce several pro-inflammatory cytokines including IL- $1 \alpha$, IL-2, IFN- $\gamma$, IL-6, IL-8 and TNF- $\alpha$ [28]. Lu increased IL-2 secretion by SW-1353 cells but had no significant effect on other proinflammatory cytokines studied. On the other hand, $\beta \mathrm{Cr}$ inhibited IL-1 IL-2 and IFN (0.01 and $0.1 \mu \mathrm{mol} / \mathrm{L})$. At 0.1 $\mu \mathrm{mol} / \mathrm{L}, \mathrm{Lu}$ tended to increase IL- $1 \alpha$, IL- 2 and IFN- $\gamma$ secretion. IL- $1 \alpha$, IL-2, and IFN- $\gamma$ are generally classified as Th1modulating cytokines due to their ability to induce immune responses that lead to autoimmune diseases such as RA. We showed that $\beta \mathrm{Cr}$, but not $\mathrm{Lu}$, has anti-inflammatory properties. These results paralleled the down-regulation of $\mathrm{NF} \kappa \mathrm{B}$ in the nuclear fractions of cells cultured with $1.0 \mu \mathrm{mol} / \mathrm{L} \beta \mathrm{Cr}$, suggesting that the down-regulation of NFKB led to decreased expression of the pro-inflammatory cytokines IL- $1 \alpha$, IL-2, and IFN- $\gamma$. The lack of a similar response with Lu cannot be explained. IL-6, IL- 8 and TNF- $\alpha$ are pivotal in driving acute rather than chronic inflammation [29]. The lack of effect of $\mathrm{Lu}$ and $\beta \mathrm{Cr}$ on IL-6, IL- 8 and TNF- $\alpha$ perhaps suggests that these two carotenoids are better suited to handle chronic inflammatory responses, as seen with OA and RA.

IL-4 and IL-10 are generally regarded as Th-2modulatory cytokines and inhibit many of the catabolic processes induced by pro-inflammatory cytokines. IL-4 is undetectable in arthritic tissue, suggesting that an imbalance in Th1/Th2-modulated cytokines drives disease progression [30]. It has also been shown that IL-4 can inhibit MMP production in cartilage explants [31]. In this study, Lu but not $\beta C r$ stimulated IL-4 production. Joosten et al. demonstrated that IL-4 treatment reduced collagen and bone destruction in DBA/-1J/Bom mice [30]. Even though IL-4 has tissueprotective properties, it is not able to act as a potent antiinflammatory cytokine. This is consistent in our study; while $\mathrm{Lu}$ increased IL-4 production, it decreased production of collagen degrading factors such as MMP-13 and $\mathrm{PGE}_{2}$. Previous research indicates that IL-10 is chondroprotective by downregulating MMP and pro-inflammatory cytokines such as IL-6 [31]. In this study, $\beta \mathrm{Cr}$ but not $\mathrm{Lu}$ increased IL-10 production. Human chondrosarcoma cells lack functional IL- 
10 receptors due to a defect in IL-10R1 surface expression, leaving cells unresponsive to IL-10 induction, therefore provides a possible explanation for the upregulation of IL-10 production by $\beta \mathrm{Cr}$ [25].

In conclusion, the carotenoids $\mathrm{Lu}$ and $\beta \mathrm{Cr}$ protect against degenerative factors upregulated by IL- $1 \beta$-induced in SW1353 cells, likely by scavenging ROS required for NFkB activation. In general, downregulation of NFKB resulted in decreased production of cytokines, mediators, and proteinases which are upregulated in OA and RA. The action of Lu and $\beta \mathrm{Cr}$ seem to be mediated through somewhat different pathways: $\mathrm{Lu}$ tended to downregulate factors involved with cartilage destruction (MMP-13 and $\mathrm{PGE}_{2}$ ) and upregulate factors involved in tissue-protection (IL-4) at the expense of downregulating pro-inflammatory cytokines; $\beta \mathrm{Cr}$ tends to downregulate factors associated with pro-inflammatory response (IL-1 $\alpha$, IL-2, and IFN- $\gamma$ ) and cartilage destruction $\left(\mathrm{PGE}_{2}\right)$, while failing to downregulate matrix-degrading proteinases. This is expected because the two carotenoids differ structurally, influencing location and orientation and interaction at the membrane. $\beta \mathrm{Cr}$ is more polar than $\mathrm{Lu}$ and therefore may exert different biological actions within the cell. These findings offer new perspectives from therapeutic approaches for treating both the symptomatic and degenerative processes characteristic of OA and RA.

\section{COMPETING INTERESTS}

The authors declare that they have no competing interests.

\section{AUTHORS' CONTRIBUTIONS}

M.M.D., B.D.M., J.S.P, and B.P.C designed the experiments, conducted experiments and analyzed data. M.M.D. wrote the first draft and B.D.M., J.S.P, and B.P.C. revised the paper. All authors read and approved the final manuscript.

\section{ACKNOWLEDGEMENTS}

This work was supported by a grant from the Agriculture Research Center, Washington State University, Pullman.

\section{REFERENCES}

[1] Dieppe PA, Lohmander LS. Pathogenesis and management of pain in osteoarthritis. Lancet 2005; 365: 965-73.

[2] Kim JH, Na HJ, Kim CK, et al. The non-provitamin A carotenoid, lutein, inhibits NF-kB-dependent gene expression through redoxbased regulation of the phosphotidylinositol 3-kinase/PTEN/Akt and NF-kB-inducing kinase pathways: role of $\mathrm{H}_{2} \mathrm{O}_{2}$ in NF-kB activation. Free Radic Biol Med 2008; 45: 885-96.

[3] Lawrence RC, Felson DT, Helmick CG, et al. Estimates of the prevalence of arthritis and other rheumatic conditions in the United States. Part II. Arthritis Rheum 2008; 58: 26-35.

[4] Helmick CG, Felson DT, Lawrence RC, et al. Estimates of the prevalence of arthritis and other rheumatic conditions in the United States. Part I. Arthritis Rheum 2008; 58: 15-25.

[5] Pashkow FJ, Watumull DG, Campbell CL. Astaxanthin: a novel potential treatment for oxidative stress and inflammation in cardiovascular disease. Am J Cardiol 2008; 101: 58-68D.

[6] Badger AM, Cook MN, Swift BA, Newman-Tarr TM, Gowen M, Lark M. Inhibition of interleukin-1-induced proteoglycan degradation and nitric oxide production in bovine articular cartilage/ chondrocyte cultures by natural product, hymenialdisine. J Pharmacol Exp Ther 1999; 290: 587-93.

[7] Shikhman AR, Kuhn K, Alaaeddine N, Lotz M. Nacetylglucosamine prevents IL-1 $\beta$-mediated activation of human chondrocytes. J Immunol 2001; 166: 5155-60.
[8] Eberhardt W, Beck KF, Pfeilschifter J. Cytokine-induced expression of tPA is differentially modulated by NO and ROS in rat mesangial cells. Kidney Int 2002; 61: 20-30.

[9] Kuo PC, Abe KY, Schroeder RA. Oxidative stress increases hepatocyte iNOS gene transcription and promoter activity. Biochem Biophys Res Commun 1997; 234: 289-92.

[10] Mangels AR, Holden JM, Beecher GR, Forman MR, Lanza E. Carotenoid content of fruits and vegetables: an evaluation of analytic data. J Am Diet Assoc 1993; 93: 284-96.

[11] Jin XH, Ohgami K, Shiratori K, et al. Inhibitory effects of lutein on endotoxin-induced uveitis in Lewis rats. Invest Ophthalmol Vis Sci 2006; 47: 2562-8.

[12] Koutsos E, Garcia Lopez J, Klasing KC. Carotenoids from in ovo or dietary sources blunt systemic indices of the inflammatory response in growing chicks (Gallus gallus domesticus). J Nutr 2006; 136: 1027-31.

[13] Pattison DJ, Symmons DP, Lunt M, et al. Dietary $\beta$-cryptoxanthin and inflammatory polyarthritis: results from a population-based prospective study. Am J Clin Nutr 2005; 82: 451-5.

[14] Gebauer M, Saas J, Sohler F, et al. Comparison of the chondrosarcoma cell line SW1353 with primary human adult articular chondrocytes with regard to their gene expression profile and reactivity to IL-1 $\beta$. Osteoarthritis Cartilage 2005; 13: 697-708.

[15] Tetlow LC, Adlam DJ, Woolley DE. Matrix metalloproteinase and proinflammatory cytokine production by chondrocytes of human osteoarthritic cartilage. Associations with degenerative changes. Arthritis Rheum 2001; 44: 585-94.

[16] Eder J. Tumor necrosis factor $\alpha$ and interleukin 1 signalling: do MAPKK kinases connect it all? Trends Pharmacol Sci 1997; 18 319-22.

[17] Kempson GE. Mechanical properties of articular cartilage. In: Freeman MAR, Ed. Adult articular cartilage. $2^{\text {nd }}$ ed. Tunbridge Wells, UK: Pitman Medical 1979; pp. 333-414.

[18] Pei Y, Harvey A, Yu XP, Chandrasekhar S, Thirunavukkarasu K. Differential regulation of cytokine-induced MMP-1 and MMP-13 expression by $\mathrm{p} 38$ kinase inhibitors in human chondrosarcoma cells: potential role of Runx 2 in mediating p38 effects. Osteoarthr Cartil 2006; 14: 749-58.

[19] Bertram JS, Pung A, Churley M, Kappock TJ, Wilkins LR, Cooney $\mathrm{RV}$. Diverse carotenoids protect against chemically induced neoplastic transformation. Carcinogenesis 1991; 12: 671-8.

[20] Mengshol JA, Vincenti MP, Coon CI, Barchowsky A, Brinckerhoff CE. Interleukin-1 induction of collagenase 3 (matrix metalloproteinase 13) gene expression in chondrocytes requires p38, c-Jun Nterminal kinase, and nuclear factor $\mathrm{kB}$ : differential regulation of collagenase 1 and collagenase 3. Arthritis Rheum 2000; 43: 80111 .

[21] Li Q, Engelhardt JF. Interleukin-1beta induction of NFkappaB is partially regulated by $\mathrm{H} 2 \mathrm{O} 2$-mediated activation of NFkappaBinducing kinase. J Biol Chem 2006; 281: 1495-505.

[22] Yamaguchi M, Uchiyama S. Combination of beta-cryptoxanthin and zinc has potent effects on apoptotic cell death and suppression of bone resorption-related gene expression in osteoclastic cells. Int J Mol Med 2008; 22: 221-8.

[23] Hamalainen M, Nieminen R, Vuorela P, Heinonen M, Moilanen E. Anti-inflammatory effects of flavonoids: genistein, kaempferol, quercetin, and daidzein inhibit STAT-1 and NF- $\mathrm{BB}$ activations, whereas flavone, isorhamnetin, naringenin, and pelargonidin inhibit only NF- $\mathrm{kB}$ activation along with their inhibitory effect on iNOS expression and NO production in activated macrophages. Mediators Inflamm 2007; 2007: 45673.

[24] Radons J, Falk W, Schubert TE. Interleukin-10 does not affect IL1 -induced interleukin -6 and metalloproteinase production in human chondrosarcoma cells, SW1353. Int J Mol Med 2006; 17: 377 83.

[25] Wada Y, Shimada K, Sugimoto K, Kimura T, Ushiyama S. Novel p38 mitogen-activated protein kinase inhibitor R-130823 protects cartilage by down-regulating matrix metalloproteinase-1, -13 and prostaglandin $\mathrm{E}_{2}$ production in human chondrocytes. Int Immunopharmacol 2006; 6: 144-55.

[26] Torzilli PA, Tehrany AM, Grigiene R, Young E. Effects of misoprostol and prostaglandin $\mathrm{E}_{2}$ on proteoglycan biosynthesis and loss in unloaded and loaded articular cartilage explants. Prostaglandins 1996; 52: 157-73. 
[27] Hung LF, Lai JH, Lin LC, et al. Retinoic acid inhibits IL-1-induced iNOS, COX-2 and chemokine production in human chondrocytes. Immunol Invest 2008; 37: 675-93.

[28] Otero M, Goldring MB. Cells of the synovium in rheumatoid arthritis. Chondrocytes. Arthritis Res Ther 2007; 9: 220.

[29] van den Berg WB. Animal models of arthritis. What have we learned? J Rheumatol Suppl 2005; 72: 7-9.
[30] Joosten LA, Lubberts E, Helsen MM, et al. Protection against cartilage and bone destruction by systemic interleukin- 4 treatment in established murine type II collagen-induced arthritis. Arthritis Res 1999; 1: 81-91.

[31] Lacraz S, Nicod LP, Chicheportiche R, Welgus HG, Dayer JM. IL10 inhibits metalloproteinase and stimulates TIMP-1 production in human mononuclear phagocytes. J Clin Invest 1995; 96: 2304-10.

(C) Di Filippo et al.; Licensee Bentham Open

This is an open access article licensed under the terms of the Creative Commons Attribution Non-Commercial License (http://creativecommons.org/licenses/by-nc/3.0/) which permits unrestricted, non-commercial use, distribution and reproduction in any medium, provided the work is properly cited. 